\title{
NOTES
}

\section{THE MODERN DAY SCARLET LETTER: A CRITICAL ANALYSIS OF MODERN PROBATION CONDITIONS}

There can be no outrage, methinks, agamst our common nature,whatever be the dehinquencies of the individual,--no outrage more flagrant than to forbid the culprit to hide his face for shame; as it was the essence of this punishment to do. ${ }^{1}$

But the poimt which drew all eyes, and, as it were, transfigured the wearer,-so that both men and women, who had been familiarly acquainted with Hester Prynne, were now impressed as if they beheld her for the first time,-was that SCARLET LETTER, so fantastically embroidered and illuminated upon her bosom. It had the effect of a spell, taking her out of the ordinary relations with humamity, and enclosing her in a sphere by herself. ${ }^{2}$

Nathamiel Hawthorne, The Scarlet Letter

\section{INTRODUCTION}

In The Scarlet Letter, Nathaniel Hawthorne describes the plight of Hester Prynne, the adulteress forced to wear a scarlet " $A$ " on her chest to show her crime. In this fictional account of seventeenth century Boston, Hawthorne's searing example of Hester Prynne embodies what then was society's use of punishment by humiliation. Curiously, proving again that "history" tends to repeat itself, some modern probation conditions resemble Hester Prynne's scarlet letter and similar forms of early punishment by humiliation.

Criminal punishnient ${ }^{3}$ can serve many purposes: retribution, rehabilitation, deterrence, or incapacitation. However, both commentators and the United States Sentencing Commission have rejected the notion that in our modern day the purpose of punishment is rehabilitation. Professor Packer wrote in 1969 that "there are two and only two ultimate

1. N. Hawthorne, The SCarlet LetTer 53 (Bantam Classic ed. 1986) (1850).

2. Id. at 51 .

3. As used in the Note, the term "punishment" refers only to criminal punishment. Many things that constitute punishment (e.g., punitive damages) are not criminal punishment. As Professor Packer has put it: "Punishment is a concept; criminal punishment is a legal fact." H. PACKER, The Limits of the Criminal Sanction 35 (1968). 
purposes to be served by criminal punishment: the deserved infliction of suffering on evildoers and the prevention of crime." 4 In addition, the Sentencing Reform Act of 1984, ${ }^{5}$ drafted by the United States Sentencing Commission, states that the purpose of punishment is retribution, education, deterrence, and incapacitation; ${ }^{6}$ the Sentencing Commission thus rejects the notion that punishment serves to rehabilitate.

While probation has as its primary goal rehabilitation, ${ }^{7}$ as a practical matter judges cannot impose probation conditions entirely devoid of punitive elements. As a result, appellate courts should evaluate the punitive elements of probation conditions to ensure that they are not pervasive, smce such punitive conditions would defeat probation's statutorily mandated goal of rehabilitation. Moreover, apart from any statutory analysis, reviewing courts should subject such punitive conditions to scrutiny under the eighth ainendinent.

The purpose of this Note is to discuss and analyze the proliferation of modern probation conditions that resemble the scarlet letter in both their purpose and effect. These conditions, though they do not involve wearing a scarlet " $\mathrm{A}$ " or the like, subject the defendant to the same public humihation and ridicule as did Hester Prynne's scarlet letter. This Note asserts that certain nodern probation conditions, those that effectively label the defendant, in fact constitute a forin of punishment. As a result, these conditions should be reevaluated critically in light of probation's primary goal of rehabilitation. ${ }^{8}$ The reevaluation should involve a "mixture" analysis-that is, judges should evaluate the totality of the probation conditions imposed in order to determine whether the mixture of conditions is within the limits of the statutory inandate. ${ }^{9}$ Characterizing probation conditions as punishment will force courts to properly himit the use of probation conditions to a mixture that comports with the rehabilitative goal of probation. Additionally, to ensure that probationers receive the same constitutional protections afforded prisoners, courts should subject punitive probation conditions to constitutional scrutiny under the eighth amendment.

This Note begins by briefly tracing the history of early forms of punishinent and ultimate means of deterrence on which early punishment rehed-public humiliation. Part III highlights a number of modern scar-

4. Id. at 36 .

5. Sentencing Reform Act of 1984 , 18 U.S.C. $\S \S 3551-86$ (1982 \& Supp. V), 28 U.S.C. $\S \S 991-$ 98 (1982 \& Supp. V). The Supreme Court upheld the sentencing guidelines as constitutional in Mistretta v. United States, 109 S. Ct. 647 (1989).

6. 18 U.S.C. \& 3553(a)(2) (1982 \& Supp. V).

7. See infra notes $68-79$ and accompanying text.

8. See infra notes 68-79 and accompanying text.

9. See infra notes 134-41 and accompanying text. 
let-letter type probation conditions. Part IV examines the accepted goals of probation and the obvious tension that exists between the punitive nature of modern probation conditions and the rehabilitative goal of probation. Following a discussion of the goals of probation, Part $\mathrm{V}$ analyzes current limitations, non-constitutional and constitutional, on judicial discretion when imposing probation conditions. After establishing such a framework, this Note argues that modern scarlet-letter probation conditions resenibling the historical antecedents of punishnient constitute punishnient by humiliation. Consequently, Part VI concludes that certam scarlet-letter probation conditions improperly mix punitive and rehabilitative conditions and, as a result, do not fulfill the statutorily mandated rehabilitative goal of probation. While such conditions are not per se improper, they should not be imposed by what aniounts to judicial legislation.

Independent of the proper mixture of probation conditions, Part VI also suggests that courts should subject punitive probation conditions to an eighth amendnient analysis. Failure to apply the eighth amendnient's "dignity of nian" standard to punitive probation conditions results in probationers receiving less constitutional protection than if they were incarcerated. ${ }^{10}$

\section{Probation as Punishment}

A fundamental flaw in both scholarly and judicial evaluations of probation conditions is the accepted prenise: It's probation, therefore it's not punishnent. ${ }^{11}$ Before any statutory or constitutional analysis can take place, the prenise that probation is punishnient must be proved. Probation conditions are not always entirely punitive in nature; nor are probation conditions and punishnent mutually exclusive. Rather, any given set of conditions niay serve to deter, rehabilitate, or punish. But the role of the courts, and the endeavor of this Note, is to look behind the labels that the conditions carry to ascertain what functional purpose is being served, and then to review the conditions in the light of that functional purpose.

10. See infra notes $142-60$ and accompanying text.

11. Some have actually assumed it without even trying to prove it. See, e.g., Springer v. United States, 148 F.2d 411, 415 (9th Cir. 1945) (since eighth amendment only applies to punishment, probation conditions not subject to constitutional scrutiny). Conversely, others have assumed that probation is punishment also without trying to prove it. See, e.g., Note, Criminal Procedure: When Hester Prynne Drives Drunk: An Examination of the Constitutional Challenges to the Requirement of a "Scarlet Bumper Sticker" as a Condition of Probation on DUI Offenses, 41 OKLA. L. REv. 529, 541 (1988) ("[b]ecause probation is a form of punishment ...."). 
A survey of scarlet-letter type probation conditions suggests that the premise that probation is "punishment" holds credence. As discussed below, scarlet-letter conditions resemble older forms of punishment by humiliation and, as this resemblance illustrates, they also fail to serve the traditional rehabilitative goal of probation.

\section{A. Public Humiliation as a Focus of Early Punishments.}

At its most primitive stages, penologists considered punishment necessary to remove the evil spirit thought to cause an individual to transgress against society. ${ }^{12}$ However, a historical examination of punishment reveals that early forms of punishment reflected man's inhumanity to man. ${ }^{13}$

Early societies divided crimes into two groups: "(1) the criminal cases calling for social action in apprehension and punishment, and (2) the civil cases (torts) which are a private matter." 14 Criminal cases were crimes against the society; accordingly, the entire community would reprimand individuals committing such crines. ${ }^{15}$ Entire tribes and villages gathered to expel the criminal from his social group. ${ }^{16}$ Punishment in this context served as a means by which the entire society collectively expressed its disapproval. Today, this function is carried out symbolically by public officials who enforce the laws of society by prosecuting criminals.

Early forms of punishment contained a strong element of gross pubhic humiliation; ${ }^{17}$ in fact, public humiliation enhanced traditional physical pumishments and functioned as punishment by itself. ${ }^{18}$ Physical punishments such as hanging, drawing, and quartering were carried out publicly in ceremonial fashion, ${ }^{19}$ thereby emphasizing the degrading nature of public executions. ${ }^{20}$ Ritualistic mutilation focused the commumity's attention on the humiliation component of punishment. As one

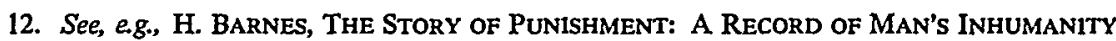
to Man 39 (1930); D. Dressler, Practice and Theory of Probation and Parole 3 (2d ed. 1969).

13. For an in-depth analysis and historical account of the history of punishments, see C. HIBBerT, The Roots of Evil (1963); G. Ives, A History of Penal Methods (1914). A good concise description of the various types of punishments not discussed in this Note can be found in $H$. McDonnell, In The Throes of Criminal Justice: A History of the Origin, DevelopMENT AND FAILURE OF OUR SYSTEM OF CRIMINAL JUSTICE 123-50 (1986).

14. H. BARNES, supra note 12, at 40 .

15. Id.

16. Id. at 42 .

17. Id. at 43 .

18. C. HIBBERT, supra note 13 , at 28.

19. Id. at 27.

20. Id. 
commentator noted, "a horrifying example was not, though, the only purpose behind [such rituals]. . . . It was also intended that the victim should be humiliated, for degradation figured largely in all contemporary theories of punishment." 21

Whereas the humiliation element of a hanging may pale against the physical element, early societies did not restrict their placement of public stigmas only to capital crimes. Late oriental and classical societies engaged in branding as a means of punishing common criminals. The Romans, French, and Enghish developed and used branding as a means of identifying crimmals by the crime that they had committed.22 Branding, a method widely used in the seventeenth century, consisted of burning a single letter representing the first letter of the crime committed onto the perpetrator's face. ${ }^{23}$ An " $M$ " would be branded on a inurderer; a " $T$ " branded on a thief. This cruel method of marking would preclude those who were branded from finding employment and thus "render[ing] them desperate."24 The American Colonies also generally used branding; ${ }^{25}$ New Jersey, for example, punished burglary by branding the criminal's hand for a first offense and her forehead for subsequent offenses. ${ }^{26}$

Flogging and the use of pillories, which developed to pumsh those criminals whose offense did not warrant the severe penalty of flogging, called for a public display of the criminal. Indeed, arguably the only purishment inflicted by the pillory was that caused by public display. Flogging, of course, imposed the additional element of physical suffering: "When the pillory was employed in a simple fashion and not accompanied by any other inode of punishment, its operation was chiefly psychological, and it was designed to bring about the feeling of humiliation naturally attendant upon the infliction of public disgrace." 27

The stocks and pillory inflicted primarily psychological rather than physical punishment. In early societies, when villages and communities were close-knit groups, to be shuuned by the entire commumity "was no trifling penalty." 28 Once the spectacle was over, those punished, although released froin punishment, never would return to their previous

21. Id.

22. H. BARNES, supra note 12, at 62 .

23. $I d$.

24. G. IVES, supra note 13, at 53.

25. H. BARNES, supra note 12 , at 67.

26. $I d$.

27. Id. at 62-63.

28. G. IVES, supra note 13, at 55 . Other examples of punishment by humiliation can be found under what one author has labeled "poetic punishments": a baker selling "short" loaves was forced to wear a loaf of bread around his neck; a fishmonger found to be selling bad fish was sentenced to wear a "collar of stinking smelts slung over his shoulder." Id. at 55-56. 
place in society. The "everybody knows everybody clse's business" mentahity that existed in the early communities ensured stigmatization.

Public humiliation or stigmatization thus played a major role in pumishment for early societies. As society developed, though, a more humamitarian approach to punishment also evolved. As a result, society began to reject these historical forms of punishment. In the late 1800 s, American courts expressed their disapproval by declaring the pillories and stocks "cruel and unusual punishment" in violation of the Constitution. ${ }^{29}$ However, some courts recently have breathed new life into niodern methods of humiliation and public disgrace, thereby reinvigorating psychological punishnent in a different form.

\section{MODERN SCARLET-LETTER CONDITIONS}

Some courts presently impose punishment by public huniliationin the form of "scarlet letter" conditions-under the guise of probation. Such punitive conditions are not inherently wrong and, in fact, niay prove particularly useful in a system strugghing to find effective methods of imposing sanctions. The problem is that courts have failed to recognize the conflict that results when scarlet-letter conditions impose punishment. Imposition of punitive probation conditions may deprive probationers of significant legal rights ${ }^{30}$ and, by exceeding statutory limitations on probation conditions, may constitute judicial legislation. A determination that such conditions are an appropriate criminal sanction is better left to the legislature. To illustrate the kinds of conditions courts have imposed, the following sections discuss several innovative scarlet-letter conditions that vary in their degree of punishment by humiliation.

\section{A. Purse Snatcher Required to Wear Tap Shoes.}

In the 1976 California case of People v. McDowell, ${ }^{31}$ the defendant was convicted of purse-snatching. ${ }^{32}$ The key to the defendant's success was his ability to sneak up silently-he usually wore tennis shoes-and make a quick getaway with his victim's purse. ${ }^{33}$ In an attempt to make the punishment fit the crime, the trial court required, as a condition of probation, that the defendant "wear leather shoes with metal taps on the

29. See, e.g., Hobbs v. State, 133 Ind. 404, 409, 32 N.E. 1019, 1021 (1893).

30. See infra notes $134-60$ and accompanying text (suggesting that probationers should be protected from the imposition of conditions that severely hamper probation's rehabilitative goal and protected from conditions that violate eighth amendment).

31. 59 Cal. App. 3d 807, 130 Cal. Rptr. 839 (1976).

32. Id. at $810,130 \mathrm{Cal}$. Rptr. at 841 .

33. Id. 
heels and toes anytime he leaves his house." ${ }^{34}$ The defendant challenged the condition as cruel and unusual and as "tantamount to hanging a sign around [his] neck that says, 'I am a thief.' "35 The California Court of Appeals found this argument unpersuasive, stating that merely because a condition is unusual or out of the ordinary does not make it constitutionally unreasonable. ${ }^{36}$ The court of appeals never addressed directly whether the condition amounted to puinshment; it did, however, reverse on grounds that the trial court's order was too imprecise. ${ }^{37}$

\section{B. Drunk Driver Required to Place Apology in Newspaper.}

In a second type of scarlet-letter case, a judge forced drunk drivers in Illinois in 1988 to place an apology and a photograph in the defendant's hometown newspaper. Judge Jeffrey Ford of the Champaign Circuit Court imposes such a condition on convicted drunk drivers because he firnily believes in its deterrent effect. ${ }^{38}$ Admonishment that occurs only within the confines of the courtroom, according to Ford, allows the defendant to reinain anonyınous; ${ }^{39}$ publicizing the defendant's name and photograph in the newspaper has the opposite effect. Defendants who appear before Judge Ford will hear him justify the sentence by telling them, "I believe that an open and public adımission ... make[s] it more likely that the defendant will not conmit further crimes."40 One can conclude that at least in the opinion of the sentencing judge, such a condition of probation acts as a deterrent because it subjects the defendant to punishınent by public humiliation.

34. Id. at $812,130 \mathrm{Cal}$. Rptr. at 842 . One could envision other courts trying to tailor the punishment to fit the crime. An interesting example of a unique condition fitting the crime would be to require a convicted kleptomaniac to wear mittens while in public to make it more difficult to steal.

35. Id., $130 \mathrm{Cal}$. Rptr. at $842-43$. One may argue that forcing the defendant to wear tap shoes all the time potentially will subject the defendant to public ridicule or embarrassment because it is not "normal" to wear tap shoes all the time in public. Such an argument fails to persuade, though, if the defendant resides in a diverse and large city that may contain any number of individuals wearing tap shoes in public. The argument may have more force, however, if the defendant resides in a small town.

36. Id., 130 Cal. Rptr. at 843.

37. Id. at $813-14,130 \mathrm{Cal}$. Rptr. at 843 . The court was concerned that interpreting the order one way would preclude the appellant from engaging in any athletic activity. Conversely, interpreting it to mean that the defendant just had to wear the shoes "as he leaves" home would render the condition ineffective. Id.

38. Tybor, Unusually Creative Judges Now Believe Some Punishments Can Fit the Times, Chicago Tribune, July $3,1988, \S 3$, at 1 , col. 1 .

39. Id.

40. Id. 


\section{Drunk Driver Required to Put Bumper Sticker on Car.}

In the 1986 Florida case of Goldschmitt v. Florida, the sentencing court required a convicted drunk driver to place a bumper sticker on his car that read: "CONVICTED D.U.I.-RESTRICTED LICENSE."41 In reviewing this probation condition, the appellate court found that the trial court judge could impose any special condition whenever she deemed it appropriate, provided that the condition bears some relationship to the nature of the offense and the condition is otherwise lawful.42 The appellate court was quick to defer to judges who assert that the bumper sticker "serves some useful purpose and that every first-time offender should have one." 43

In challenging the probation condition, defendant Goldschmitt analogized the bumper sticker to the practice of the pillory during colomal times. He also argued that the sticker violated the eighth amendment's prohibition against cruel and unusual punishment. The appellate court rejected this argument, stating that "the differences between the degradimg physical rigors of the pillory and a small strip of colorful adhesive far outweigh the similarities. The mere requirement that a defendant display a 'scarlet letter' as part of his punishment is not necessarily offensive to the Constitution." 44

The Goldschmitt court appears to have concluded that creativity in sentencing by judges, particularly in the probation context, should not be suppressed unless clearly unconstitutional. In fact, the court notes that submitting defendants to public disgrace often will heighten the deterrent and rehabilitative impact of punishment. ${ }^{45}$ The Goldschmitt court, and other courts, ${ }^{46}$ consider such "behavioral sanctions" imposed as conditions of probation to be appropriate, particularly for white-collar criminals. ${ }^{47}$ The court, however, did issue one caveat: "[S]uch innovative dispositions can be carried to extremes which might offend constitu-

41. Goldschmitt v. Florida, 490 So. 2d 123, 124 (Fla. Dist. Ct. App. 1986) (court rejected a first amendment challenge to such a condition). For a comprehensive analysis of the case, see Case Comment, The Bumper Sticker: The Innovation That Failed, 22 NEW ENG. L. REv. 643 (1988).

42. Goldschmitt, 490 So. $2 \mathrm{~d}$ at 125 \& n.3.

43. Id. at 125.

44. Id. (emphasis added); cf. Case Comment, supra note 41 , at 658 (concluding that the bumper sticker violates the amendment by being constitutionally excessive in that it does not contribute to the acceptable goals of punishment).

45. Goldschmitt, 490 So. $2 \mathrm{~d}$ at 125 (quoting United States v. William Anderson Co., 698 F.2d 911, 913 (8th Cir. 1982)).

46. See, e.g., United States v. William Anderson Co., 698 F.2d 911, 914 (8th Cir. 1982) (court upheld condition of probation imposed upon a corporate defendant requiring payment of fine to be reduced dollar for dollar by the amount of contributions made to charitable organizations).

47. Goldschmitt, 490 So. $2 \mathrm{~d}$ at 125. 
tional standards." 48 Thus, whereas the court held that the bumper sticker was not sufficiently humiliating to trigger constitutional objections, ${ }^{49}$ the Goldschmitt court clearly left open the possibility that a future condition of probation could be sufficiently humiliating to warrant striking it down as unconstitutional.

In reaching its conclusion, the court never clearly states that the eighth amendment provides the basis for its analysis. However, its determination that the bumper sticker condition does not rise to a level of constitutionally prohibited public humiliation stands in response to the appellant cliallenging the condition as cruel and unusual. In addition, although the Goldschmitt court does not exphicitly consider whether such conditions of probation constitute pumishınent, the court continually refers to probation conditions, such as requiring a bumper sticker, as "punishınent."

Finally, the Goldschmitt court buttressed its holding, that the buinper sticker condition does not violate constitutional limits, with its appellate review policy. The court stated that it should not second-guess a lower court's finding tliat a bumper sticker is "rehabilitative," uuless it finds the condition to be "utterly without foundation." 51

\section{Child Molester Required to Post Warning Signs.}

A final, most recent case, which may approach the level of constitutional objection discussed in Goldschmitt, is the 1989 Oregon case of State v. Bateman. ${ }^{52}$ In Bateman, the court placed a convicted child molester on probation for five years subject to a condition, among others, that he place a sign on both sides of his car and on the door of his residence stating in three-inch lettering: "DANGEROUS SEX OFFENDER-NO CHILDREN ALLOWED."53 Bateman had been

48. Id. at 126. An example of such an extreme condition is illustrated by Bienz v. State, 343 So. 2d 913 (Fla. Dist. Ct. App. 1977). In that case, a probationer who was ordered into a halfway house was additionally required to comply with all orders given by employees of the halfway house. Id. at 914. One such order was that the probationer, who was accused of acting like a baby, was told to wear diapers over his regular clothing. Although the case was resolved on other grounds, the court took the opportunity to comment on the condition of wearing a diaper: "[S]uffice it to say that a command ... that an adult male wear diapers in public would certainly be demeaning in the minds of, so called, reasonable men. ... [N] ot surprisingly, prior decisions involving such bizarre incidents are sparse." Id. at 915.

49. Goldschmitt, 490 So. $2 d$ at 126.

50. Id. at 125 .

51. Id. at 126.

52. State v. Bateman, 95 Or. App. 456, 464, 771 P.2d 314, 318 (1989) (held limited scope of review on appeal does not allow court of appeals to determine if conditions of probation are validly imposed).

53. Brief for Appellant at A-2, State v. Bateman, 95 Or. App. 456, 771 P.2d 314 (1989) (Or. App. No. A 44854) [hereinafter Brief for Appellant]. 
convicted previously of sexually abusing a child. ${ }^{54} \mathrm{He}$ had committed acts of child molestation after offering unsuspecting children candy and soda and luring them into his home. ${ }^{55}$ Judge Dorothy Baker was concerned that if she placed Bateman in prison, he would be released without supervision.

In explaining why she imposed such a novel punishment, Judge Baker expressed frustration and hostility towards child molesters: "One time, I thought of dyeing all [child molesters] green and telling children to stay away from green people." 56 Judge Baker justified her requirement that the offender post signs as a response to the "lack of community recognition of dangerous people." 57 She hoped that even if the signs did not actually deter individuals like Bateman, they at least would be a warning to children whom he might otherwise lure into his trap. ${ }^{58}$

The defendant challenged the condition on a number of grounds including the eighth amendment. He argued that the requirement of posting such signs amounted to the court treating him as non-human. ${ }^{59}$ His counsel argued that the

[d] efendant will be at best shunned from society and at worst subjected to physical harassment and abuse. In placing him on probation, the court is in effect telling him that he is capable of reforming his conduct ... while at the same time, in imposing these conditions, also informing him that he does not deserve to be treated as a human being. ${ }^{60}$

The defendant, in trying to distinguish the signs from the bumper sticker upheld in Goldschmitt, argued that child molesters differ significantly from drunk drivers. Since children hold a sacred place in society due to their youthful innocence, offenses against them are condemned more readily than other kinds of offenses.

In response to Bateman's eighth amendment challenge, the State argued that probation generally is not considered punishment and that probation has been viewed as an "act of grace" by which the defendant is given the choice ${ }^{61}$ to avoid "punishment." 62 The State's response to the

54. Brief for Respondent at 4-7, State v. Bateman, 95 Or. App. 456, 771 P.2d 314 (1989) (Or. App. No. A 44854) [hereinafter Brief for Respondent].

55. Id. at 4-5.

56. Silverman, A Modern-Day Scarlet Letter for a Sex Offender, 9 Nat'1 L. J., Aug. 31, 1987, at 9, col. 1 .

57. $I d$.

58. See id.

59. Brief for Appellant, supra note 53, at 22.

60. Id. at 23.

61. See Note, Judicial Review of Probation Conditions, 67 CoLUM. L. Rev. 181, 188-91 (1967). The author correctly argues that the "act of grace" theory suggests that constitutional limitations upon conditions do not exist if the defendant is granted the privilege of probation. Id. at 190. However, the author argues that this act-of-grace theory has given way to the "unconstitutional conditions" doctrine. Id. That is, "conditions imposed upon the granting of privileges and gratuities 
appellant's eighth amendment argument was that "the United States Supreme Court has generally imterpreted the clause as being 'specifically concerned with the unnecessary and wanton infliction of pain in penal institutions' ... or as a last resort basis for reviewing whether an imposed sentence of imprisonment is grossly disproportionate to the crime."63 The thrust of the State's rejection of the eighth amendment argumentaside from probation not being a form of punishment-was that warning signs on the defendant's house and car do not rise to the level of extreme punishment (such as death, unnecessary and wanton infliction of pain, or unusually long incarceration) that has been the core of eighth amendment jurisprudence. ${ }^{64}$

The State based its argument in Bateman on the flawed premise that if imprisonment of ten years is constitutional, it follows a fortiori that probation, which is less of an infringement, is also constitutional. ${ }^{65}$ Such an argument, taken to its logical conclusion, requires that any condition imposed on a probationer must survive constitutional muster because such a condition is a substantially less severe infringement on the defendant's liberty ${ }^{66}$ than imprisonment or the death penalty. But this line of reasoning ultimately fails because many crimmal sanctions other than the death penalty, including disproportionate imprisonment, have been struck down as unconstitutional. Thus, it follows that certain conditions of probation, even though they do not impose the ultimate sentence, may be found unconstitutional.

The above illustrations of scarlet-letter conditions differ in their unusualness, severity, and degree of punishment by humiliation. ${ }^{67}$ These conditions, though effective, are controversial because they fall on the

must be 'reasonable.'" Id. at 191 (citing Speiser v. Randall, 357 U.S. 513, 518 (1958)). Such an analysis would run parallel to a contract theory of probation. Note, supra, at 191. This theory suggests that the probationer has entered into a contract with the judge to be on probation. Because a person cannot consent, and have enforced, an illegal contract, this theory too should not restrict a probationer's right to challenge conditions.

62. Brief for Respondent, supra note 54 , at 24.

63. Id. at 32 (quoting Whitley v. Albers, 475 U.S. 312 (1986)) (citations omitted) (citing Solem v. Helm, 463 U.S. 277 (1983)).

64. Brief for Respondent, supra note 54, at 34.

65. Id. at 27 .

66. This argument is rejected by many courts, which hold that a condition of probation must be analyzed for what it is. These courts reason that a condition of probation must be analyzed against what probation is meant to do. See, e.g., Walker v. State, 461 So. $2 d 229$ (Fla. Dist. Ct. App. 1984) (invalidating, as not furthering probation's goal of rehabilitation, a condition that required the defendant to purchase an amount of merchandise equivalent to the amount he had stolen and returned).

67. At the less severe end of the spectrum is the requirement that the defendant wear tap shoes. At the most severe end of the spectrum is the condition requiring that a drunk driver place an apology and her picture in the newspaper or that a child molester be required to identify himself as such. 
line between punishment and probation. These provocative innovations call for a reexamination of the current limitations on the courts' power to impose probation conditions-a reexamination that must be made in light of probation's statutory goals.

\section{The Goals of Probation}

\section{A. Rehabilitation-Probation's Primary Goal.}

Probation represents a modern innovation in the history of criminal sanctions, one that reflects the evolution of the humanitarian movement in criminology. ${ }^{68}$ Probation has been defined as: "A sentence not involving confinement which imposes conditions and retains authority in the sentencing court to modify the conditions of sentence or to resentence the offender if the offender violates the conditions."69 Probation is designed "to aid the rehabilitation of a penitent offender; to take advantage of an opportunity for reformation which actual service of the suspended sentence might make less probable."70 Courts generally state that the priniary purpose of probation "is to rehabilitate the offender."71 In addition, many state statutes explicitly provide that probation should

68. H. Allen, C. Eskridge, E. Latessa, \& G. Vito, Probation and Parole in america 36 (1985) [hereinafter H. ALLEN].

69. Id. at 42. Other definitions include: "Probation is a disposition that allows the convicted offender to remain free in the community while supervised by a person who attempts to help him lead a law-abiding life." S. Rubin, The LAw of Criminal Correction 205 (2d ed. 1973).

70. Burns v. United States, 287 U.S. 216, 220 (1932).

Section 1.2 of the American Bar Association's Project on Standards for Criminal Justice states the reasons behind imposing probation instead of traditional sentences in appropriate cases:

Probation is a desirable disposition in appropriate cases because:

(i) it maximizes the liberty of the individual while at the same time vindicating the author-

ity of the law and effectively protecting the public from further violations of law;

(ii) it affirmatively promotes the rehabilitation of the offender by continuing normal community contacts;

(iii) it avoids the negative and frequently stultifying effects of confinement which often severely and unnecessarily complicate the reintegration of the offender into the community;

(iv) it greatly reduces the financial costs to the public treasury of an effective correctional system;

(v) it minimizes the impact of the conviction upon the innocent dependents of the offender. ABA Project on Standards for Criminal Justice, Standards Relating to Probation, approved draft, $\S 1.2$ (1970) [hereinafter ABA Project].

71. Higdon v. United States, 627 F.2d 893, 897 (9th Cir. 1980). A court should not try to rehabilitate an individual at the expense of protecting the public. See also, People v. Keller, 76 Cal. App. 3d 827, 840, 143 Cal. Rptr. 184, 192 (1978) (a requirement of waiver of fourth amendment rights as a condition of parole for theft of a pen found not to be a reasonable means of achieving rehabilitation); Hines v. State, 358 So. 2d 183, 185 (Fla. 1978) (because probation revocation procedures must comport with due process, a proof of arrest in and of itself is not sufficient grounds for permanent revocation of probation); State v. Mummert, 98 Idaho 452, 454, 566 P.2d 1110, 1112 (1977) (rule prohibiting defendant from purchasing an automobile held to be reasonably related to his rehabilitation, but rule prohibiting operation of an automobile without permission was not reasonably related to rehabilitation). 
be used to rehabilitate. ${ }^{72}$ Probation accomplishes rehabilitation by returning the individual to the community and by assisting her in becoming a law-abiding citizen. ${ }^{73}$ Probation conditions that are designed to help further rehabilitation imclude: reporting regularly to a probation officer; getting and keeping a job; attending school regularly; keeping reasonable hours; avoiding indebtedness; abstaining from using illegal substances; and avoiding disreputable places and associates. ${ }^{74}$ If no probation conditions are imposed, probation effectively equals release; on the other hand, conditions that are too restrictive or cumbersome may defeat probation's rehabilitative goal or unconstitutionally infringe on an individual's liberties. For example, a condition of probation that amounts to suppression of an individual's freedom of expression would violate the first amendment. ${ }^{75}$

In order to treat defendants sinilarly, a court generally considers and applies a standard "Taundry list" of conditions, ${ }^{76}$ and after imposing standard conditions, a judge will individualize the probation conditions. ${ }^{77}$ When individualizing such conditions, however, courts have ignored the rehabilitative goal of probation. In recent years, courts have been especially active in tailoring punitive probation conditions as a re-

72. See e.g., ARK. STat. ANN. § 5-4303(a) (1987 \& Supp. 1989) ("assist the defendant in leading a law abiding life"); ConN. GEN. STAT. ANN. §53a-30(a)(9) (West 1985 \& Supp. 1989) (any conditions reasonably related to his rehabilitation); IOWA CODE ANN. $\S 907.7$ (West 1987) ("The purposes of probation are to provide the maximum opportunity for the rehabilitation of the defendant ...."); ME. REv. STAT. ANN. tit. 17A, § 1204-2-m (1983) ("reasonably related to ... rehabilitation"); N.M. STAT. ANN. § 31-20-6(F) (1989) ("reasonably related to . . rehabilitation"); OHIO REV. CODE ANN. $\S 2951.02$ (c) (Anderson 1987) (rehabilitate offender).

73. H. ALLEN, supra note 68, at 37 ("Probation is ... tied to the correctional goals of rehabilitation and reintegration, providing the potential benefits to the offender as well as the community.").

74. See D. DRESSLER, supra note 12 , at 242-50.

75. Porth v. Templar, 453 F.2d 330, 334 (10th Cir. 1971).

76. See, e.g., OR. REV. STAT. $\S 137.540$ (1) (1988). The statute provides that a probationer will be subject to the following conditions:

(a) Remain under the supervision and control of the probation department.

(b) Abide by the direction of the probation department and its representatives.

(c) Promptly and truthfully answer all reasonable inquiries of the probation officer relating to probation performance.

(d) Truthfully report monthly at times and in a manner specified by the probation department or its representative.

(e) Remain in the State of Oregon until written permission to leave is granted by the probation department or its representatives.

(f) Find and maintain gainful full-time employment, approved schooling, or a full-time combination of both.... $\ldots$

(j) Obey all laws, municipal, county, state and federal.

(k) Pay fines, costs including probation costs, attorney fees or restitution or any combination thereof ordered by the court on a schedule of payments determined by the court.

77. See G. Killinger, H. Kerper, \& P. Cromwell, Probation and Parole in the CRIMINAL JUSTICE SYSTEM 81 (1976) (citing National Advisory Commission's Correction Standards, $\$$ 5.4 Commentary 159-60 ("Conditions should be tailored to fit the needs of the offenders and society ....")). 
sponse to prison overcrowding, the cost of building new prisons, and public disappointment with traditional punishınents. ${ }^{78}$ Creative judges have gone to new lengths to make the punishinent fit the crime, ${ }^{79}$ sonietimes imposing probation conditions that qualify more as punishment than rehabilitation. Illustrative of such punitive conditions are the scarlet-letter conditions previously discussed, since conditions of this sort result in the imposition of punishment by humiliation, while ostensibly falling under the rubric of probation.

\section{B. The Effect of Modern Probation Conditions Resembles the Effects of Early Forms of Punishment.}

The scarlet-letter probation conditions previously discussed ${ }^{80}$ exist on a continuum. At one end of the continuuin are those conditions that only superficially resenble historical precedents; arguably the one requiring the defendant to wear tap shoes would fall at this end. ${ }^{81}$ Whereas such a condition has punitive elements, they tend to be outweighed by the close relationship of the condition imposed to the crine committed; the condition directly thwarts a crucial element of the defendant's crininal conduct and is consistent with the goal of rehabilitation. ${ }^{82}$

At the other end of the continuuin are those conditions that in their effect at least, closely resemble the stocks and pillories. At this end stand those conditions, for example, that require the defendant to place a bumper sticker on his car, his picture and an apology in the newspaper, or a sign labeling him a convicted child molester on his residence and car. ${ }^{83}$ These conditions subject the defendants to public ridicule by labeling them as criminals. These conditions are distinct from that of merely requiring the defendant to wear tap shoes because a bumper sticker or an apology in the newspaper announces to the world the probationer's con-

78. See Weissman, Constitutional Primer on Modern Probation Conditions, 8 New ENG. J. ON Prison LAW 367, 369-73 (1982).

79. Some of the more creative sentences include: a slumlord ordered to spend 30 days in one of his rundown, rat-infested buildings; a woman convicted of pirating cable television service was told not to watch cable TV shows for one year; a drug dealer who fathered three children outside of a marriage was ordered to remain celibate for five years unless he got married. Tybor, supra note 38, at 1 , col. 3.

More recently, judges have required a convicted child molester to place an apologetic ad in his hometown newspaper, and one judge in Florida required four men who allegedly stole crabs from a trap to walk up and down a local bridge wearing placards stating that they were convicted of molesting crabs, which is a felony in Florida. M. Brarrigan \& K. Blumenthal, Courts Using Humiliation as Punishment, Wall St. J., Nov. 9, 1989, at B11, col. 1.

80. See supra notes $30-67$ and accompanying text.

81. See supra notes 31-37 and accompauying text.

82. See supra note 35 .

83. See supra notes $38-67$ and accompanying text. 
viction. In contrast, wearing tap shoes in public, while possibly out of the ordinary, does not tell the world anything about the individual's criminality. As the appellant in State v. Bateman argued, "[The] Defendant will be at best shunned from society and at worst subjected to physical harassment and abuse"84; that is the price the defendant Bateman will have to pay for his "rehabilitative" probation.

The other defendants will have to pay a similar price, since each of these conditions lead to legally imposed publicity. In contrast to the public stigma these probationers will carry, an individual who is incarcerated is able to remain relatively anonymous since she does not walk around "announcing" her conviction to society. ${ }^{85}$ Thus, such scarletletter probation conditions impose punishment in the form of humiliation, in inuch the same way as the historical sentences that punished by humiliation.

\section{The Tension Between Punitive and Rehabilitative Conditions.}

As the preceding discussion suggests, modern scarlet-letter probation conditions create an obvious tension between probation's primary goal of rehabilitation and the "judicially created" goal of punishment. Thus, although statutes ${ }^{86}$ and judicial opinions ${ }^{87}$ recognize rehabilitation as the primary goal of probation in practice, courts disagree about the extent to which punishment is also a proper function of probation. ${ }^{88}$ The resulting tension, and the lack of any creative flexibility within the statutory framework, has provoked some courts to characterize obviously punitive probation conditions as "rehabilitative." 89 Such a characterization, however, could suggest erroneously that every condition of probation is rehabilitative.

The court's language in Villery v. Florida Parole and Probation Commission ${ }^{90}$ illustrates the confusion (convenient or otherwise) that stems

84. Brief for Appellant, supra note 53, at 23.

85. Such an argument is similar to the one that Judge Ford made in justifying the imposition of a probation condition that required the defendant to apologize publicly in the newspaper. See supra notes $39-40$ and accompanying text.

86. See supra note 72.

87. See, e.g., Higdon v. United States, 627 F.2d 893, 897 (9th Cir. 1980) ("primary purpose of probation is to rehabilitate the offender"); People v. Keller, 76 Cal. App. 3d 827, 838, $143 \mathrm{Cal}$. Rptr. 184, 191 (1978); Hines v. State, 358 So. 2d 183, 185 (Fla. 1978); State v. Mummert, 98 Idaho 452, 454, 566 P.2d 1110, 1112 (1977).

88. Compare Springer v. United States, 148 F.2d 411, 415 (9th Cir. 1945) (conditions of probation are not punitive in nature) with Cooper v. United States, 91 F.2d 195, 199 (5th Cir. 1937) (probation is a form of mild and ambulatory punishment) and Scheidt v. Meredith, 307 F. Supp. 63, 66 (1970) (probation clearly contains punitive elements).

89. See, e.g., Villery v. Florida Parole \& Probation Comm'n, 396 So. 2d 1107 (Fla. 1980).

90. 396 So. 2d 1107 (Fla. 1980). 
fron1 a blurring of the line between punitive and rehabilitative measures. The Villery court first stated that imprisonnent penalizes the defendant by requiring him to repay his debt to society. Yet the sanie court also asserted that imprisonment is a "rehabilitative device" when iniposed as a condition of probation. ${ }^{91}$ Such a characterization represents an awkward attenipt by the court to stay within the state's probation statute. Courts have shown a disturbing tendency to define an obviously punitive probation condition as "rehabilitative," simply because their state statute allows them to impose rehabilitative conditions but does not allow then to impose punitive conditions. ${ }^{92}$

A second explanation, although no less critical of the linguistic games courts are playmg, is that these judges are engaging in judicial legislation. Constrained by their state probation statutes, judges attenipt to rewrite their respective statutes to include punishnient as a goal of probation. In either case, courts such as the Villery court grant themselves power beyond that allowed by statute in imposing probation conditions.

As several coninientators have suggested, "[a] more realistic approach would be to recognize that punishnent, like rehabilitation, can be a valid rationale for imposing a probation ... term. The two are not mutually exclusive." 93 Indeed, probation conditions can have both punitive and rehabilitative elements, as well as other characteristics. ${ }^{94}$ Courts need not characterize probation conditions as necessarily either punishment or rehabilitation; rather courts should be candid and honest in labeling the conditions they impose on probationers. For example, a fine imposed as a condition of probation should be labeled correctly as a punitive condition-as punishment-whenever it falls under the rubric of a probation condition. Only when courts recognize that sone probation conditions also have punitive characteristics will the inadequacy of current limitations on judicially iniposed probation conditions beconie clear. The inadequacy of hinitations results when courts fail to strike down conditions in cases in which the punitive characteristics outweigh rehabilitative concerns, and thereby fall outside statutory authority. In addition, if courts acknowledge that probation conditions are punitive in nature, that will enable defendants to receive proper review of their punishınent by challenging such conditions under the eighth aniendment.

91. Id. at 1110 .

92. See supra note 72 and accompanying text.

93. N. Cohen \& J. Gobert, The Law of Probation and Parole, $\$ 5.01$, at 185 (1983).

94. Probation also serves a deterrent function, and, in some instances, probation may constitute restitution. See H. AlleN, supra note 68, at 86. 


\section{Limitations on Judicial Discretion to Impose Conditions . OF Probation}

Two broad categories of sources generally limit judicial discretion in imposing probation conditions. The first centers on non-constitutional limitations, and a number of cases defining the nature of these limitations. The second mvolves constitutional ${ }^{95}$ limitations. ${ }^{96}$

\section{A. Non-Constitutional Limitations.}

Non-constitutional97 limitations confine judicial discretion in imposing probation conditions by prohibiting conditions that camiot be utilized generally as a penal sanction agamst any defendant. ${ }^{98}$ In addition, nonconstitutional limitations require the court to consider the "reasonableness" of the probation conditions imiposed. As a part of the "reasonableness" inquiry, courts review the condition to ensure that it furthers the iniplicit or explicit statutory goals of probation. A number of recent cases from federal and state courts help define these limitations and illustrate how they work (or fail to work) in practice.

As a general proposition, probation conditions that cannot be in1posed as penal sanctions involve conditions that contravene public policy. For exaniple, since a court cannot impose banishment as a penal sanction, ${ }^{99}$ such a condition is also invalid as a condition of probation. In People v. Baum, ${ }^{100}$ the sentencing court ordered the defendant to "leave the state of Michigan withm 30 days and not return for [the] period of probation,' which was fixed at five years."101 The Michigan Supreme Court, in reversing the lower court, noted that although banishment was permitted at common law, states should not engage in "dumping" convicted criminals imto other states. Such a policy, said the court, would "disturb that fundaniental equality of political rights among the

95. For purposes of this Note, references to the constitution mean the Umited States Constitution. When discussed within the context of a specific state, it will be assumed that the applicable state constitution wording is the same unless otherwise noted.

96. This Note only explores an eighth amendment limitation. See infra notes 142-60. For a more in-depth discussion of other constitutional challenges, such as the first, fourth, and fifth amendments, see e.g., Weissman, supra note 78.

97. This category is used in a Note discussing in great detail all elements of judicial review. See Note, supra note 61 , at 181 . Under a section entitled non-constitutional limitations, the author discusses disfavored forms of punishment and fulfilling the purposes of probation. Id. at 197-201.

98. This argument was stated in United States v. Consuelo-Gonzalez, 521 F.2d 259, 264 (9th Cir. 1975) ("II]t is virtually certain that those restraints that have been held improper when placed on prisoners ... will also be unsuitable as probation conditions . . ..").

99. See, e.g., Dear Wing Jung v. United States, 312 F.2d 73, 76 (1962).

100. 251 Mich. 187, 231 N.W. 95 (1930).

101. Id. at 188,231 N.W. at 96 (citing trial court's order). 
several states."102 The Michigan Supreme Court thus found that the probation condition contravened public policy. ${ }^{103}$

Judicial discretion in imposing probation conditions also must be confined within the goals of probation, and this requirement is enforced in some state statutes that explicitly or implicitly impose a "reasonableness" standard on probation conditions. ${ }^{104}$ Several commentators have suggested that this standard "lias four interrelated dimensions, each attempting to accommodate the conflicting interests of permitting probationers ... to be free from undue restraint while allowing necessary restrictions on their behavior." 105 They posit that a "reasonable" probation condition: (1) must satisfy one or more of the statute's rationales for allowing probation; (2) must further the goals of probation; (3) must not be impossible or extremely difficult to follow; and (4) must be appropriate im light of the crime committed. ${ }^{106}$

Similarly, in People v. Dominguez, ${ }^{107}$ a California court elaborated a three-part reasonableness test:

A condition of probation which (1) has no relationship to the crime of which the offender was convicted, (2) relates to conduct which is not in itself crimmal, and (3) requires or forbids conduct which is not reasonably related to future criminality does not serve the statutory ... [goals] of probation and is invalid. ${ }^{108}$

In applying its own test, the Dominguez court concluded that requiring a defendant convicted of robbery to abstain from future pregnancy was invalid. ${ }^{109}$ The court reasoned that "[c]ontraceptive failure is not an indicium of criminality." 110

An interesting case in which a court held that the goals of probation were not met by the probation conditions imposed is Higdon v. United States. ${ }^{111}$ In this case, Higdon pleaded guilty to defrauding the govern-

102. Id.

103. Another court has termed such banishment as being either cruel and unusual or a violation of due process. That court did not label which it was; rather, it stated flatly that the "condition is unconstitutional." Dear Wing Jung v. United States, 312 F.2d at 76. On the other hand, conditions of probation requiring the probationer to remain within a specified geographic region have become standard. See, e.g., OR. REv. STAT. $\$ 137.540$ (1)(e) (1988) (probationer must remain in the state of Oregon until written permission to leave is granted).

104. See infra notes 107-20 and accompanying text. For statutes expressly requiring that conditions be reasonable, see supra note 72; MODEL PENAL CODE § 301.1 (Proposed Official Draft 1962). For cases reading this reasonableness standard into the state's statutes, see e.g., Watson v. State, 17 Md. App. 263, 301 A.2d 26 (1973); Louk v. Haynes, 223 S.E.2d 780 (W. Va. 1976).

105. N. COHEN \& J. GOBERT, supra note 93 , § 5.09, at 209-10.

106. $I d$.

107. 256 Cal. App. 2d 623, 64 Cal. Rptr. 290 (1967).

108. Id. at 627, 64 Cal. Rptr. at 293.

109. $I d$.

110. Id.

111. 627 F.2d 893 (9th Cir. 1980). 
ment of several hundred thousand dollars. As a result, the sentencing court ordered the defendant to forfeit his assets, including his home, to the government and to work for a charity-full-time and without salary-for three years. ${ }^{112}$ The United States Court of Appeals for the Ninth Circuit found that these conditions taken together did not fulfill the goal of probation"13 because "[t]he primary purpose of probation is ... rehabilitat[ion]." "114 The court of appeals concluded that the cumulative effect of the probation conditions was "not reasonably related to reliabilitation of the offender."115

Another case, Loving v. Commonwealth, ${ }^{116}$ is an example of a case in which the conditions imposed could have constituted either an improper penal sanction or an unreasonable probation condition. The case mvolved defendants who had violated Virgima's miscegenation law, ${ }^{117}$ and the trial judge suspended their sentence upon the condition that they leave the state and not return together for twenty-five years. The Virgiria Supreme Court, instead of analyzing and striking down the banishment as against public policy, ${ }^{118}$ applied a reasonableness standard, which required that the conditions must be "reasonable, having due regard to the nature of the offense, the background of the offender and the surrounding circumstances." 119 In setting aside the trial judge's order, the court focused on the reasonableness of the condition in relation to its goal of preventing future violations. The court stated: "The condition reasonably necessary to aclieve the purpose was that the defendants not again cohabit[ate] as man and wife in this state." 120 Therefore, the banishment condition was deemed invalid since no additional condition was necessary to fulfill the purpose of the probation statute.

112. Id. at 896.

113. Id. at 899. The court did however indicate that if separated, any one of the conditions could stand alone and be valid. Id. at 899-900. For other cases holding unique conditions of probation not serving the goals of probation, see, e.g., Walker v. State, 461 So, 2d 229 (Fla. Dist. Ct. App. 1984) (invalidating as non-rehabilitative a condition of probation that required defendant to purchase an amount of merchandise equivalent to amount he had stolen despite fact that the merchandise had been returned). For cases holding unique probation conditions do serve the goals of probation, see, e.g., Mangiapane v. State, 178 Ga. App. 836, 344 S.E.2d 756 (1986) (condition that convicted drunk driver complete written requirements of Boy Scout Merit Badge on subjects of traffic safety and citizenship upheld as fostering goals of probation).

114. Higdon, 627 F.2d at 897 ; see also supra note 72.

115. Higdon, $627 \mathrm{~F} .2 \mathrm{~d}$ at 898 .

116. 147 S.E.2d 78 (Va. 1960), rev'd 388 U.S. 1 (1967).

117. VA. CODE ANN. $\S 20-58$ (1960) (repealed by Acts of Assembly April 2, 1968).

118. The Supreme Court subsequently struck down the statute in Loving v. Commonwealth, 388 U.S. 1 (1967); see also supra notes 99-103 and accompanying text (discussion of case in which court held banishment contravenes public policy).

119. Loving, 147 S.E.2d at 83.

120. Id. 
Whereas the non-constitutional limitations discussed above provide a framework within which a sentencing judge can exercise discretion in imposing probation conditions, these limitations fail to address the proper mixture of punitive and rehabilitative conditions of probation. ${ }^{121}$ In determining whether a condition is reasonable, the court focuses only on whether that condition serves a proper goal of probation. If the condition meets that test, the condition passes muster despite the presence of punitive elements. Unfortunately, courts never take the next step to weigh the elements against each other to determine if, overall, the punitive elements of the probation conditions outweigh the rehabilitative elements.

\section{B. Constitutional Limitations.}

The United States Constitution also limits the discretion of trial court judges when they impose probation conditions. Traditionally, this constitutional dimension to probation orders has been submerged under the "act of grace" theory of probation, and, as a result, this theory has severely curtailed constitutional challenges to probation conditions. ${ }^{122}$ The recent rejection of this theory, ${ }^{123}$ however, has enabled probationers to challenge probation conditions on both constitutional and non-constitutional grounds.

A number of amendments in the Bill of Rights have provided the basis for constitutional challenges to probation conditions. Use of the first ${ }^{124}$ and fourth ${ }^{125}$ amendments as vehicles for reviewing (and setting aside) probation conditions has stirred controversy in both cases ${ }^{126}$ and

121. See infra notes $134-41$ and accompanying text.

122. There is no constitutional right to be rehabilitated, People v. Osslo, 323 P.2d 397, cert. denied, 357 U.S. 907 (1958), and thus a criminal has no right to be placed on probation. Rather, whether probation is warranted is a discretionary decision once the judge deems the defendant an appropriate candidate for probation. She then may place the defendant back into society under conditions she deems to be appropriate.

123. See supra note 61 .

124. U.S. CONST. amend. I provides: "Congress shall make no law respecting an establishment of religion, or prohibiting the free exercise thereof; or abridging the freedom of speech, or of the press ...."

125. U.S. CONST. amend. IV provides: "The right of the people to be secure in their persons, houses, papers, and effects, against unreasonable searches and seizures, shall not be violated ...."

126. For first amendment challenges, see, e.g., Porth v. Templar, 453 F.2d 330 (10th Cir. 1971) (unconstitutional to prohibit an individual convicted of violating the tax laws from speaking out and questioning their constitutionality as long as defendant does not encourage others to violate the law); Morris v. State, $44 \mathrm{Ga}$. App. 765, 162 S.E. 879 (1932) (error in the imposition of a sentence, which limited defendant's first amendment rights during probation, was not sufficient reason for setting aside the verdict and trying the accused again for guilt or innocence); $c f$. United States v. Workman, 585 F.2d 1205 (4th Cir. 1978) (federal probation officers must obtain a search warrant in absence of recognized exceptions to fourth amendment; evidence obtained through a warrantless search of probationer's home is inadmissible in a federal probation revocation hearing); Latta v. Fitzharris, 521 
commentaries. ${ }^{127}$ In addition, courts occasionally have used the eighth amendment to strike down a condition of probation. ${ }^{128}$ Except for these few instances, however, the eighth amendment issue has never been fully addressed by either a court or commentator. ${ }^{129}$ The reason for the absence of a thorough eighth amendment analysis is unclear, but the Ninth Circuit's 1945 decision in Springer v. United States ${ }^{130}$ may partially explain the judicial hesitation to engage in an eighth amendinent analysis.

In Springer, the court of appeals affirmed the district court's decision placing a World War II draft dodger on probation subject to a condition, annong others, that he donate a pint of his blood to the Red Cross Blood Bank within thirty days. ${ }^{131}$ The court im Springer addressed in dictum the issue whether the condition anounted to cruel and unusual punishment: "The conditions of probation are not punitive in character and the question of whether or not the terms are cruel and unusual and thus violative of the Constitution of the United States does not arise for the reason that the Constitution apphies only to pumshment."132 The recent trend towards puritive probation conditions suggests that Springer's conclusory analysis is outdated. Modern analysis shows that conditions of probation may constitute punishment. Scarlet letter condi-

F.2d 246 (9th Cir.) (en banc) (parole officer's warrantless search of parolce's home upon arrest was reasonable; use of the evidence obtamed during that search was not limited to parole revocation proceedings), cert. denied, 423 U.S. 897 (1975).

127. See, e.g., Weissman, supra note 78, at 374-75; Note, supra note 61, at 204-05.

128. U.S. CoNST. amend. VIII provides: "Excessive bail shall not be required, nor excessive fines imposed, nor cruel and unusual punishments inflicted."

For a discussion of a case in which the Court has engaged in an eighth amendment analysis, see infra notes 130-32 and accompanying text. See also Dear Wing Jung v. United States, 312 F.2d 73, 76 (1962) (condition of probation amounting to banishment is either cruel and unusual punishment or a denial of due process and thus unconstitutional).

129. The issue has been addressed summarily by a number of cominentators. See, e.g., Note, supra note 61, at 205-06 (suggesting, in three paragraphs, that the eighth amendment applies to probation conditions " $[\mathrm{w}]$ ithout attempting to delineate the substantive content of the eighth amendment"); Note, Limitations Upon Trial Court Discretion in Imposing Conditions of Probation, 8 GA. L. REv. 466, 484-85 (1974) (summarily stating the court's conclusion that "probation is in no way a form of punishment is erroneous").

130. 148 F.2d 411 (9th Cir. 1945).

131. Id. at 415 .

132. Id. The court's holding with respect to the condition amounted to no holding at all. The two concurring judges, whose votes made the decision unanimous, stated that because the question was not properly before them, "we withhold any ruling." Id. The concurring judges in dictun stated that as far as they were concerned the condition was void on its face as "invading the physical person in an unwarranted manner." Id. at 416.

Amazingly, the decision has been interpreted in a variety of confiicting ways. See, e.g., Fiore v. United States, 696 F.2d 205, 208 (2d Cir. 1982) (requirement of donating blood upheld); United States v. Pastore, 537 F.2d 675, 679 \& n.11 (2d Cir. 1976) (same); United States v. Consuelo-Gonzalez, 521 F.2d 259, 264 (9th Cir. 1975) ("this court summarily rejected the condition that the probationer donate a pint of blood"); Tamez v. Texas, 534 S.W.2d, 686, 691 n.6 (Tex. Crim. App. 1976) (same). 
tions that humiliate by labeling "inflict suffering on the evildoer" and as such constitute punishment, not rehabilitation..$^{133}$ It is time for courts to set aside semantics and appropriately label probation conditions as having punitive, rehabilitative, or other characteristics. Courts then can analyze whether they have achieved the proper mixture of punitive and rehabilitative conditions. Moreover, a court can independently analyze those conditions found to be punitive under the eighth aniendnient. The current system of limitations on judicial discretion obfuscates the punitive aspect of probation and inakes considered and independent analysis impossible.

\section{Probation As Punishment: So What?}

Having concluded that certain probation conditions inflict punishment, one may ask the question: "So what?" That is, does the conclusion that probation conditions inflict punishnent, in and of themselves, beg the question whether these probation conditions exceed statutory authority or constitute cruel and unusual punishment in violation of the Constitution?

\section{A. The Non-Rehabilitative Goal of the Modern Mixture of Probation Conditions.}

The punitive aspects of sonie scarlet-letter probation conditions is far renioved from, and indeed almost antithetical to, the rehabilitative goal of probation. As discussed above, probation "is in large part concerned with avoiding future crimes by helping the defendant learn to live productively in the community which he has offended against." 134 Onerous conditions that largely punish also severely haniper the rehabilitative goal and may transform probation into punishnient.

Reexamination of inodern scarlet-letter conditions ${ }^{135}$ in light of probation's rehabilitative function helps to distinguish those conditions that are essentially punitive from those that are rehabilitative. Since society has inoved away froin psychological punishinents, the degree to which scarlet-letter probation conditions huniliate the probationer provides an important indicator in analyzing whether such conditions constitute punishment. Applying this analysis, one could argue, for exaniple, that requiring a probationer to wear tap shoes is a condition whose purpose runs parallel to one of the ainis of rehabilitation-specific deterrence. To require such defendants to conform their conduct to the iniposed condi-

133. See supra notes 4-7 and accompanying text.

134. ABA Project, supra note 70, Introduction, at 1.

135. See supra notes 30-67 and accompanying text. 
tions enables the court to encourage the individual to become a law-abiding citizen; the probationer has a constant reminder that, by eliminating the basic tool of the crime, ${ }^{136}$ reduces the defendant's inclimation to give into his particular vice. In addition, the simple fact of wearing tap shoes may not itself announce to the world a person's criminal conviction for purse-snatching. ${ }^{137}$ Thus, although the probation condition may have punitive eleinents-since wearing tap shoes inflicts a modicum of humiliation and suffering-a balancing of the elements tilts less towards pumtive than towards rehabilitative.

Analysis also shows that requiring a drunk driver to place a bumper sticker on her car, identifying herself as a convicted drunk driver with a restricted hicense, also serves the goal of rehabilitation. Every time the driver gets into her car, the bumper sticker will remind her of the criminal conviction, and she will give notice to everyone who reads her bumper of that conviction. In a sense, she is being legally required to publicize her conviction, thereby subjecting her to public humiliation. However, she may choose not to drive in order to avoid subjecting herself to humiliation or enibarrassment. This result would be ideally rehabilitative since it completely deters the probationer from driving. Alternatively, she may choose not to engage in the activity that resulted im probation; if she chooses to drive, the bumper sticker may reinind her constantly of her offense, ${ }^{138}$ reinforce the gravity of her offense, and encourage her to refram from drunk driving. Therefore, although the buinper sticker potentially subjects the defendant to humiliation and embarrassinent, the punitive aspect does not outweigh the strong rehabilitative or deterrent effects of the condition.

On the other hand, careful review shows that requiring a drunk driver to place his picture and an apology im the newspaper is more punitive than the bunper sticker. The bumper sticker defendant can voluntarily avoid potential humiliation; the other defendant calmot voluntarily avoid the apology in the newspaper. The defendant suffers humiliationa forn of punishinent-as a result of the legally imposed publicity, which amounts to forcing the defendant to air his "dirty laundry" for the world to see. However, while the picture and apology are more pumtive than a buniper sticker, they also have rehabilitative and deterrent effects. ${ }^{139}$

136. The tap shoes prevented the purse snatcher from sneaking up on his victims.

137. See supra note 35.

138. It is possible to argue that a reminder on the dashboard would serve this same purpose better than the bumper sticker. While arguably true, no court to date has tried such a requirement probably because a sticker on the dashboard does not involve the imposition of humiliation.

139. The deterrence and rehabilitation functions are intertwined in the notion that the offender will refrain from drunk driving to avoid the condition being imposed again. 
Nevertheless, in the "mix" of rehabilitation and punishment, the rehabilitative element does not outweigh the punitive aspect of humiliation.

A clearer case in which the punitive aspect looms large against the rehabilitative element is the probation condition that requires a convicted child nolester to place signs on his residence and automobile. Analysis shows that this condition steps over the hine-it is more punitive than rehabilitative. Certainly, one could argue that such a sign is necessary to protect the public and to warn children of the danger this individual presents. ${ }^{140}$ Whereas this argument may be valid, tle punitive effects of requiring the defendant to publicize lis conviction in nearly every aspect of lis life clearly outweigli the reliabilitative effects. The signs will humiliate the defendant and cause the general public to disassociate themselves from the defendant. Moreover, it will frustrate one of the primary purposes of probation: to reintegrate the defendant nito society. The condition effectively places the defendant in a prison within society. As the ABA lias stated:

Other things being equal, the odds are that a given defendant will learn how to hive successfully in the general community if he is dealt with in that community rather than shipped off to the artificial and atypical environinent of an institution of confineinent. Banishinent froin society, in a word, is not the way to integrate someone into society. ${ }^{141}$

Placing sigus on the defendant that announce liis conviction of cliild molestation wlierever lie goes creates an "artificial environment" in the commumity into which the defendant inay be reintegrated. Therefore, in the "mix" of conditions, this legally imposed publicity constitutes inore pumsliment tlian reliabilitation.

Scarlet-letter probation conditions in any given case may constitute punishment. Certain scarlet-letter conditions impose punishment by humiliation and may hamper severely probation's statutorily inandated rehabilitative purpose. For that reason, courts sliould be honest in their approacli and should accept that certam conditions of probation contain pumitive elements. Such an approacl will enable tliem, consistent with mandated statutory guidelines, to determine if the iniposed probation aclieves the proper mixture of conditions. Independent of whether the mixture of probation conditions fall within the statutory guidelines, punitive probation conditions slould be analyzed for conformity witl the eightli amendment.

140. In fact, such an argument was advanced by the State in this case. See Brief for Respondent, supra note 54 , at $49-50$.

141. ABA Project, supra note 70 , at 1. 


\section{B. Modern Probation Conditions Should Be Subject to an Eighth Amendment Analysis.}

A brief review of the substantive content of the eighth amendment and policy justifications for eiglitlı amendment application indicates that, independent of wlietlier a court has achieved the proper mixture, probation conditions im appropriate cases can and should be struck down as cruel and unusual punishment.

\section{Substantive Content of the Eighth Amendment. One commen-} tator lias described the eighth amendment's prohibition of cruel and unusual pumshment"142 as "a flexible tool for protecting the values underlying its language." ${ }^{143}$ In Trop v. Dulles, ${ }^{144}$ the Supreme Court developed this interpretation, stating that the meaning of the eiglitl amendment inust be drawn from "tlie evolving standards of [hunian] decency that mark the progress of a maturing society." 145 Only Justice Black's concurring opinion in McGautha v. California ${ }^{146}$ has challenged this interpretation. However, no otlier court has questioned Trop witli any urgency. ${ }^{147}$

Further exploration of the standard enunciated in Trop leads to the conclusion that certain scarlet-letter probation conditions can be struck down under suclı a standard. As Trop stated, "tlie basic concept under-

142. The Supreme Court has never drawn a distinction between the words "cruel" and "unusual." The "cases [examining the distinction] indicate that the Court simply examimes the particular punishment involved im light of the basic prohibition against inhuman treatment, without regard to any subtleties of meaning that might be latent in tlie word "unusual.' " Trop v. Dulles, 356 U.S. 86, 100-01 n.32 (1957). If "unusual" is to be given a special meaning, then it slould be an ordinary one. Id. "Unusual" normally would mean sometling different than that which is ordinarily done. Id. The Trop Court thus concluded that denationalization was of such anomalous quality that it would meet the test of being unusual. Id.

143. Wheeler, Toward a Theory of Limited Punishment: An Examination of the Eighth Amendment, 24 STAN. L. REv. 838, 845 (1972). The author reaclies this couclusion by proving the negative. That is, if it is a fixed standard, the question then becomes: "Which particular punishments did the framers intend to proscribe, and is the chalienged pumishment among them?" Id. at 842-43. Such logic would lead to the proscription of hanging, whipping, and cropping ears, as they were the only ones mentioned during the debate over the eighth amendment. I ANNALS OF CoNG. 754 (1789).

144. 356 U.S. 86 (1957).

145. Id. at 101. See also Gregg v. Georgia, 428 U.S. 153, 171 (1976) (eighth amendment șhould be interpreted "in a flexible and dynamic manner").

146. 402 U.S. 183, 225-26, vacated, 408 U.S. 941 (1971). Justice Black stated that a flexible approach effectively would give judges legislative power. Id. However, the force of such concurrence is minimal considering that the case involved a constitutional due process challenge to unbridied jury discretion in death penalty cases; therefore, the eiglitl amendment was not even at issue in the case.

147. E.g., Atiyeh v. Capps, 449 U.S. 1312, 1315 (Rehnquist, Circuit Justice 1981) (cursorily attacking district court's reliance on Trop's dignity of man standard), motion to vacate stay denied, 450 U.S. 975 (1981). 
1ying the Eighth Amendinent is nothing less than the dignity of man."148 This standard embodies the ideal that society today is more civilized and, as society has evolved, so too have its methods of punishment. Society would not, for example, sanction a penalty of twelve years of hard labor in chains for falsifying public records. ${ }^{149}$ Likewise, society should not sanction a probation condition that effectively deprives a inan of his digmity by holding him out for public ridicule in every aspect of his life. ${ }^{150}$

Although Trop v. Dulles did not consider the punitive elenients of probation conditions in its eighth ainendment analysis, the reasoning of the court equally apphies to probation conditions. If one accepts the previously stated conclusion that probation conditions are a form of punishment, ${ }^{151}$ no qualitative distinction bars an application of the eighth amendment to punitive probation conditions with the same rigor as it is applied to traditional punishments. Accordingly, the eighth amendment's dignity of man standard should apply to probation conditions.

Under the "unusualness" standard of the eighth ainendnient, a condition of probation requiring the convicted defendant to continue to label himself a criminal would certainly be seen by today's standard as unusual. Society has made a judgnient to allow its imprisoned crininals to rejoin society with relative anonymity after serving tlieir sentences, and has permitted probationers to reniain relatively anonymous after their return to society for reliabilitation. ${ }^{152}$ Thus, modern society lias rejected completely metliods of punishment like branding and the pillory, and the humiliation associated with them. Any condition that requires a defendant to label himself (e.g., the child inolester with signs on lis car and home) or to be shunned by his fellow citizen violates Trop's concept of the dignity of man.

A case that illustrates this possibility is Bateman. ${ }^{153}$ Because Bateman cannot remain anonymous, the neighbors of this convicted child molester will lave the opportunity to inflict inhumane punishnient on

148. Trop, 356 U.S. at 100 (emphasis added).

149. Weems v. United States, 217 U.S. 349 (1910).

150. Such a case was illustrated earlier in State v. Bateman, supra notes 52-66 and accompanying text, which required a convicted child molester to announce to the world his conviction by placing signs on his car and home.

151. See supra notes $80-85$ and accompanying text.

152. Total anonymity is nearly impossible in this day and age of mass media and live television coverage of trials. Although accepting "societal" imposed publicity, legislatures have not yet embraced the notion of legally imposed publicity as punishment. To the contrary, it is common to find in statutes an allowance for the expungement of records to totally avoid disclosure. Therefore, such legally imposed publicity should not be sanctioned as a condition of probation until such time as the legislatures deem it appropriate.

153. State v. Batemen, 95 Or. App. 456, 771 P.2d 314 (1984); see supra notes $52-66$ and accompanying text. 
him. Therefore, a court should strike down, as cruel and unusual, a condition such as this one that requires a child molester to place a sign on his car and residence. ${ }^{154}$

2. Policy Arguments Supporting Application of the Eighth Amendment to Probation Conditions. Reinforcing the conclusion that "the dignity of man" concept applies to probation conditions are policy arguments supportimg the apphication of the eighth amendment to probation conditions.

First, a failure to apply the eighth amendment to probation conditions permits judges to have unbridled discretion in imposing conditions of probation. Since state statutes currently provide no limitation, ${ }^{155}$ allowing judges to impose punitive conditions arbitrarily allows them to erode the legislative goals of probation. The end result is that probation becomes another form of purishment and not an alternative to punishinent.

The goal of modern probation statutes is rehabilitation, not punishment. 156 Until legislatures redefine this statutory purpose, judges should respect probation's purpose by imposing only those conditions that primarily serve its rehabilitative goals. The eighth amendment supplies the framework within which to maximize this result. Subjecting probation conditions to an eighth amendment analysis forces judges to scrutinize carefully those persons who are convicted and to utilize probation only when it is appropriate. Therefore, an application of the eighth amendment would conform probation conditions to the rehabilitative model and would prevent judges from arbitrarily imposing probation as another form of purishment.

Second, by failing to apply the eighth amendinent to probation conditions, courts afford probationers less constitutional protection than prisoners. Prisoners have experienced widespread success in challenging prison conditions under the eighth amendment. ${ }^{157}$ On the other hand, courts continually have turned away probationers from the courthouse without eighth amendinent protection because they are not being "pun-

154. The result of striking down such a condition as cruel and unusual will not impact the defendant's position as a probationer. Challenges to conditions of probation can involve upholding some conditions while striking down others. Therefore, the probationer does not risk probation being revoked by challenging the conditions imposed.

155. The statutes only require that the conditions be reasonable. See supra note 72 .

156. Id.

157. See, e.g., Hutto v. Finney, 437 U.S. 678, 687 (1978) ("taken as a whole, conditions in the isolation cells continued to violate the prohibition against cruel and unusual punishment"). 
ished."158 Because modern scarlet-letter probation conditions clearly have punitive elenents, ${ }^{159}$ the eighth amendnient must apply in order to preserve probationers' constitutionally protected rights.

\section{Application of the Eighth Amendment to Modern Probation Con-} ditions. Reexamination of modern scarlet-letter probation conditions in light of Trop's dignity of man standard could cause certain probation conditions to be struck down. The analysis above shows that requiring the purse snatcher to wear tap shoes would not violate Trop's standard because, by wearing tap shoes, the defendant is not publicizing his conviction. Whereas the bumper sticker and the apology in the newspaper each require a defendant to publicize her conviction, one could argue, especially in the case of the bumper sticker, that the limited nature of the publicity keeps the condition within the boundaries of Trop. The apology im the newspaper is within Trop's boundaries because of the limited duration of the exposure and the lack of a direct physical connection between the defendant and the apology. On the other hand, the child molester who is required to announce his conviction to the world in nearly every aspect of his life, including the sanctity of his home, suffers liumiliation and punishment that transgresses the dignity of man standard. Described in Nathaniel Hawthorne's words, the child molester is "tak[en] . . out of . . ordinary relations with humanity, and enclos[ed] ... im a sphere by [him]self." 160

\section{CONCLUSION}

Innovative judges sliould be comniended for having the courage to impose creative sentences. When their creativity strays too far, however, appellate courts should reevaluate the trial court's exercise of discretion. No coherent himitation is currently available to appellate judges who review lower court's imposition of probation conditions. Courts should put semantics aside and accept that probation conditions are a tool of punishment, as well as rehabilitation. Until the legislature changes the probation statute to include punisliment as a proper goal of probation, sentencing judges' discretion should be curbed so that they use probation conditions in an appropriate manner. In the nieantime, courts should strike down probation conditions whose "mixture" contains more pun-

158. See, e.g., Springer v. United States, 148 F.2d 411, 415 (9th Cir. 1945) (because the conditions of probation are not punitive in character, eighth amendment questions do not apply to conditions of probation that are intended to be an amelioration of the punishment prescribed by law).

159. See supra notes 30-67 and accompanying text.

160. N. HAWTHORNE, supra note 1 , at 51 . 
ishment than rehabilitation as conditions that are outside statutory authority.

In addition, because modern scarlet-1etter probation conditions constitute punishment in and of themselves, they should be subjected to the eighth aniendment's "dignity of man" standard. While not necessarily striking down all such conditions, an eighth amendment review will further curb judicial discretion until the legislature acts. Absent proper statutory or constitutional review, judges often may thwart the goals of probation statutes by imposing conditions that punish instead of rehabilitate. Until proper review begins, probationers will continue to enjoy less protection than is rightfully available to them.

Jon A. Brilliant 